\title{
Cloning, Sequencing, and Overexpression of Gene 16 of Salmonella Bacteriophage P22
}

\author{
BETTINA UMLAUF AND BRIGITTE DREISEIKELMANN ${ }^{1}$
}

Universitat Bielefeld, Fakultät fur Biologie, Lehrstuhl fü Gentechnologie/Mikrobiologie, Postfach 8640, 4800 Bielefeld, Germany

Received December 3, 1991; accepted February 5, 1992

\begin{abstract}
It has been suggested that gene product 16 of bacteriophage P22 forms a pore for DNA transfer and/or that it functions as a pilot protein guiding the DNA across the membrane. We have cloned gene 16 and determined the nucleotide sequence. Within the sequenced region there is an open reading frame that could encode a protein of 609 amino acids having a molecular weight of 64,366 . The hydropathic plot of this protein does not reveal putative membrane-spanning regions as expected for a protein forming a membrane pore. Overproduction of gene product 16 in Escherichia coli was successful only in a mutant in which the La protease was inactivated. Gene 16 mutants of phage P22 were not able to infect recBCD mutants of Salmonella typhimurium nor was protein 16, synthesized in $E$. coli from a plasmid, able to substitute for the pilot protein of phage T4. It seems that gene product 16 is not a pilot protein in the meaning of binding to the ends of linear DNA, thus protecting it from degradation by nucleases. (c) 1992 Academic Press, Inc.
\end{abstract}

\section{INTRODUCTION}

There are several biological processes that involve DNA transfer across a bacterial membrane, such as infection by bacteriophages, conjugation, and genetic transformation. Although there exist many studies dealing with the identification of genes involved in DNA transport, the mechanism of this process is poorly understood. Infection, conjugation, and transformation share at least the following general features: (i) For the initiation of the DNA transport a receptor is postulated on the surface of the recipient cell, (ii) the DNA crosses the membrane in the form of a complex consisting of DNA and pilot proteins and/or DNA-binding proteins, and (iii) a preexisting or newly formed pore in the membrane is needed for the uptake of the DNA-protein complex.

Bacteriophage P22 encodes at least three proteins that are essential for the DNA ejection/injection process (Israel, 1977). These three proteins, the products of genes 7,16 , and 20 , are therefore good candidates for proteins involved in DNA transfer. It could be shown by photoinactivation experiments that in the phage particle the proteins of genes 7,16 , and 20 are closely associated with the phage DNA (Bryant and King, 1984). Phage mutants with a defect in gene 16 have been well characterized (Hoffman and Levine, $1975 a, b)$. Gene product 16 is required at an early stage of the infection process and also at a late stage as it is incorporated in progeny phage particles. Infection and transduction require gp16 but induction of the prophage does not. Protein 16 can act in trans since

\footnotetext{
1 To whom reprint requests should be addressed.
}

phage 16 mutants can be complemented in mixed infections by uv-inactivated wildtype phages. Gene 16 mutants normally adsorb to the cells and release at least the greater part of their DNA from the capsid; however, there is no expression of phage-specific genes. Thus it was postulated that gp 16 may be involved either in the complete release of the phage DNA from the capsid or in guiding the DNA to the appropriate compartment of the host cell (pilot function). There also exists the hypothesis that gp 16 could act as a hexamer forming a pore for the transfer of P22 DNA across the cytoplasmic membrane (Hoffman and Levine, 1975b; Labedan and Goldberg, 1981).

In order to investigate these different hypotheses it would be helpful to isolate and characterize the protein. We have therefore cloned the gene and successfully overproduced the gene product as a first step in analyzing its function in DNA uptake.

\section{MATERIALS AND METHODS}

Bacterial strains, bacteriophages, and plasmids

The pUC13 (Vieira and Messing, 1982) derivatives were propagated in Escherichia coli JM $101 \Delta / a c$ pro, thi, supE44 [ $\mathrm{F}^{\prime}$ traD36, proAB, lacla $\left.\mathrm{Z} \Delta \mathrm{M} 15\right]$. The expression of genes from plasmid pJF118HE (Fürste et al., 1986) was done in E. coli $\mathrm{C} 600 \mathrm{~F}^{-}$, thi-1, leuB6,

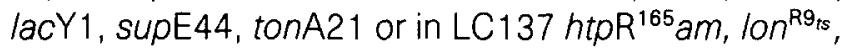
lac, trp, pho, rpsL, supC $\mathrm{t}_{\mathrm{ts}}$, mal, tsx::Tn 10, which was a gift from J. Collins. E. coli E835 recA56, recB21, su', strA was used for propagation of phage T4 $2^{-}$. Salmonella typhimurium LT2 prototroph su' (DB21, Botstein et al., 1973) and $s u^{+}, c y s_{a m}$ were from H. Schmieger. S. 
typhimurium recBC531::Tn10 was obtained from the Salmonella Genetic Stock Centre (SGSC595). Bacteriophages P22 16am34, 16ts, and $12 \mathrm{amH} 80$ were provided by the phage collection of $\mathrm{H}$. $\mathrm{H}$. Prell (Bode et al., 1973).

\section{Transformation}

The transformation of $E$. coli $\mathrm{Ca}^{2+}$ cells was performed as described (Maniatis et al., 1982). Transformation of $S$. typhimurium was done by electroporation using a Bio-Rad Gene Pulser.

\section{DNA sequencing}

DNA sequencing was performed by the chain-termination method of Sanger (Sanger et al., 1977) of deletion derivatives of hybrid pUC13 plasmids created by use of the "nested deletion kit" from Pharmacia. For DNA synthesis the T7 sequenase kit from U.S. Biochemical Corp. was used (Tabor and Richardson, 1987).

\section{SDS-PAGE of $E$, coli proteins}

Total protein for SDS-PAGE was prepared as described (Lanka and Barth, 1981). Samples of $10 \mu \mathrm{l}$ were applied to polyacrylamide slab gels $(17.5 \%$ polyacrylamide, $1 \mathrm{~mm}$ thick, $13 \mathrm{~cm}$ long) prepared as described (Laemmli, 1970). Electrophoresis was performed at 50 $\mathrm{mA}$ for about $3 \mathrm{hr}$. Gels were stained with Coomassie brilliant blue $\mathrm{G}-250$. The protein marker mix from Pharmacia contained phosphorylase $b$ (mol wt 94,000), BSA (mol wt 67,000), ovalbumin ( $\mathrm{mol}$ wt 43,000), carboxyanhydrase (mol wt 30,000), trypsin inhibitor ( $\mathrm{mol}$ wt 20,100), and $\alpha$-lactalbumin (mol wt 14,400).

\section{Construction of plasmid pBU516}

The $5^{\prime}$ end of gene 16 was amplified by PCR using the following primers:

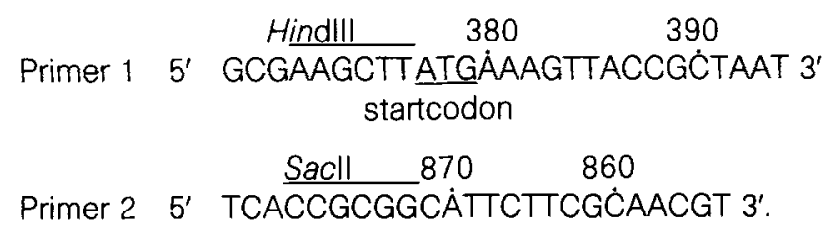

Numbers above the sequence correspond to the nucleotide position in Fig. 3 .

\section{RESULTS}

\section{Mapping of gene 16 by subcloning experiments}

On the physical map of phage P22, gene 16 is located on a Sall-EcoRI DNA restriction fragment of about $6 \mathrm{~kb}$ (Chisholm et al., 1980). Since gene 16 is part of a large operon with the promoter located outside of the Sall-EcoRI DNA fragment (Casjens and Adams, 1985), this fragment was inserted into the multicopy vector $\mathrm{pUC} 13$ to allow expression from the lacUV5 promoter. The hybrid plasmid, termed pBU1, was used for further subcloning. A 2.5-kb Sall-Nrul fragment was deleted between the lacUV 5 promoter and the startpoint of gene 16 . The resulting plasmid pBU2 carried an insert of $3.5 \mathrm{~kb}$. Plasmid pBU2 was used for the production of a series of deletion derivatives by partial degradation of the insert with exonuclease III and $S 1$ nuclease in the $5^{\prime}$ region of gene 16 (Fig. 1).

Hoffman and Levine (1975a) have shown that a P22 mutant defective in gene 16 can be complemented by a functional gp 16 from a second phage in mixed infections. That means the early function of gp16 can be complemented at the membrane. We utilized a transcomplementation assay to select for clones producing an active gp16. This complementation assay, however, is due to the late function of gp16. The gp 16 synthesized from a plasmid should be incorporated into particles of gene 16 mutants, allowing them to infect their host in the following infection cycle. A suppressor-negative strain of $S$. typhimurium was transformed by electroporation with the hybrid plasmids previously established in E. coli. The plasmid-bearing Salmonella strains were infected by P22 16am34 phages which had been propagated in a suppressor strain. These phages are able to infect a suppressor-negative strain but they can produce infectious progeny phages only if a functional gp 16 is provided by a plasmid. The plating efficiencies on the different plasmid-carrying suppressor-negative strains were compared to those on a suppressing host (Fig. 1). The progeny phages were plated again under permissive and nonpermissive conditions to distinguish between progeny phages resulting from complementation or recombination. About $30 \%$ of the progeny phages were recombinants. With the complementation assay the gene 16 was limited to a region of about $2.0 \mathrm{~kb}$ (pBU5). Plasmids with inserts smaller than pBU5 were no longer able to complement.

\section{Nucleotide sequence of the gene 16 region}

For the determination of the nucleotide sequence of gene 16, pBU3 (2.2-kb insert) was used. The sequencing strategy is summarized in Fig. 2. From analysis of proteins from $\mathrm{P} 22$ phages it is known that gp 16 has a molecular weight in the range of 67,000-69,000 (Youderian and Susskind, 1980). Within the sequenced region there is only one open reading frame that could 


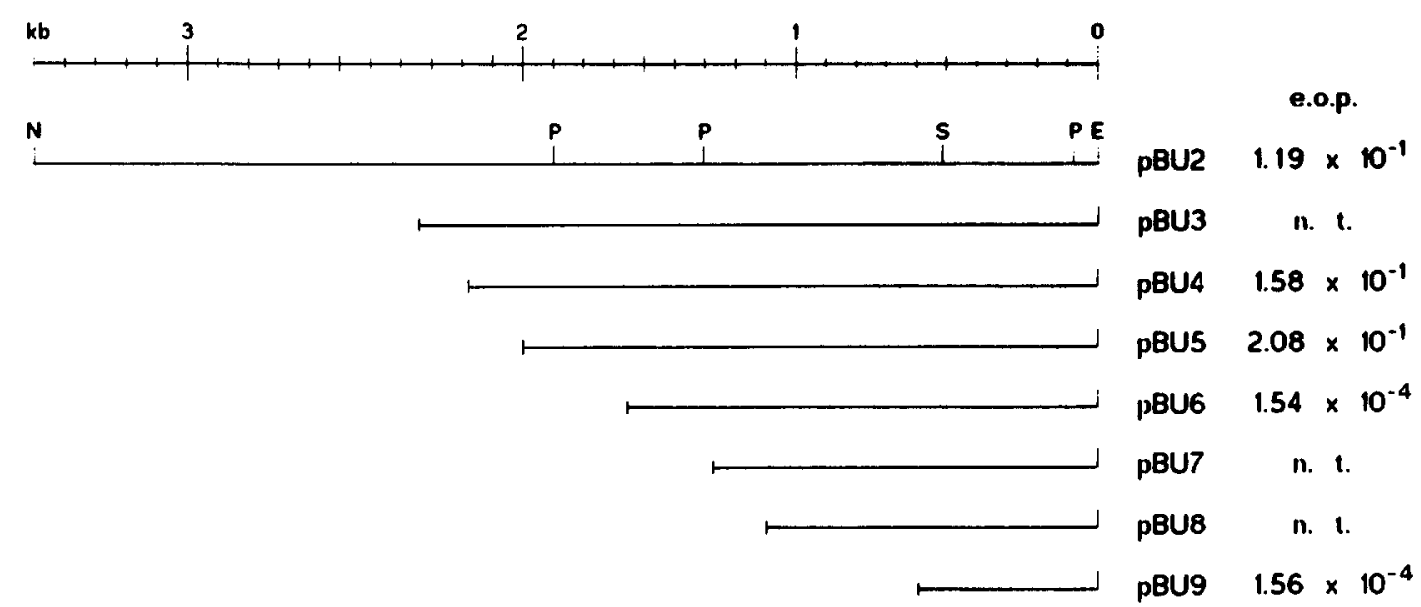

Fig. 1. Deletion derivatives of plasmid pBU1 and their effect on the efficiencies of plating (e.o.p.) of P22 gene 16 mutants. The size of the insert DNA was determined from the mobility of the DNA fragment during electrophoresis on a 1.2\% agarose gel. The e.0.p. of phage P22 16 am34 on a suppressing host was taken as 1 (titer about $8 \times 10^{9}$ ). Under nonpermissive conditions the phage plated with a relative e.o.p. of $1.5 \times 10^{-4}$ due to revertants in the lysate. (N, Nrul; P, Pstl; S, Sacl; E, EcoRI).

encode a protein of such a molecular weight. The open reading frame starts at nucleotide 377 and ends at nucleotide 2203 (Fig. 3). The possible protein of 609 amino acids would have a molecular weight of 64,366 . As expected there is no promoter in the $5^{\prime}$ region; a sequence resembling an ideal Shine-Dalgarno sequence is not present either.

If gp 16 forms a pore for the phage DNA transport across the host membrane as proposed (Goldberg, 1980; Labedan and Goldberg, 1981), then the protein should have some hydrophobic regions long enough to span the membrane. The hydropathic plot of the hypothetical protein indicates that there are no hydrophobic regions (Fig. 4). This is also supported by calculations of the hydropathic index according to Kyte and Doolittle (1982) which is always below +1.6 at any part of the protein (window of 19 amino acids).

\section{Overproduction of gene product 16}

In order to initiate studies on the biological function of gp16 during P22 infection, the protein has to be

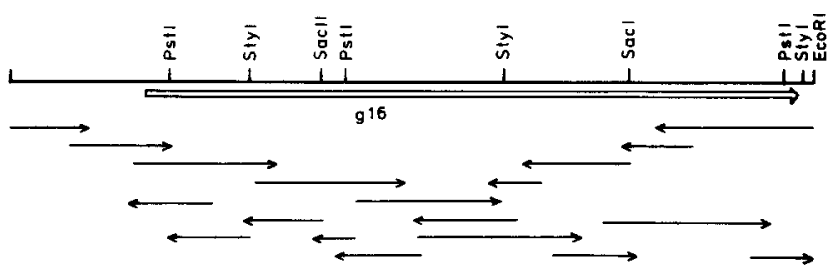

FIG. 2. Strategy for the nucleotide sequence determination of a 2.2-kb DNA fragment carrying gene 16 . The sequence of the upper strand was mainly determined with the aid of deletion derivatives (see Fig. 1) and the universal primer. The lower strand was mainly determined using synthetic oligonucleotide primers complementary to sequences of the upper strand. purified in sufficient quantities. For this purpose the $2-\mathrm{kb}$ insert of pBU5 (beginning with nucleotide 343 , Fig. 3) was inserted into different expression vectors with the $p_{L}$ promoter of phage lambda, a promoter of phage T7, or the tac promoter (pBU216). None of the hybrid plasmids resulted in overproduction of a $64-\mathrm{kDa}$ protein when the total protein of induced cells was analyzed by SDS-PAGE.

As there is no good Shine--Dalgarno sequence in front of gene 16 and the Shine-Dalgarno sequence of pJF118 is 63 bp from the start codon in plasmid pBU216, the Hindll-Sacll fragment of plasmid pBU5 was replaced by a HindlII-Sacll PCR product representing the $5^{\prime}$ end of gene 16 (Fig. 3). A new Hindlll site, directly in front of the start codon, was constructed by the primer; the Sacll recognition site is located at position 875 (Fig. 3). PCR-amplified DNA was hydrolyzed with restriction endonucleases HindIII and Sacll and inserted into pBU5 digested with the same enzyme (pBU516). To ensure that gene 16 was not mutated by PCR amplification, we measured its biological activity by the complementation assay. The plating efficiency of gene 16 mutants of P22 on a strain with pBU516 was almost as high as that found on a suppressing host (relative e.o.p. 0.8 and 1, respectively). The total insert of pBU516 (HindlII-ECoRI) was then integrated into pJF118Ht. In the resulting plasmid pBU316, the start codon of gene 16 is located $15 \mathrm{bp}$ from the Shine-Dalgarno consensus sequence of vector $\mathrm{pJF} 118 \mathrm{HE}$. Although an active gene product could be identified by the biological test, overproduction of the protein in E. coli C600 extracts was not observed. In order to test for the function of the promoter and Shine--Dalgarno sequence, the lacZ gene was fused to 


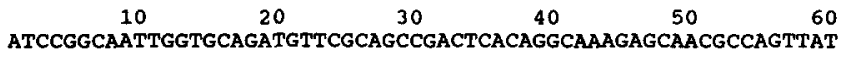
$\begin{array}{cccccc}70 & 80 & 90 & 100 & 110 & 120 \\ \text { ATAACTCCGCACAACGTATTCAGGGAAGAATGCAGAATCAGGGCGTGGCAGCAGCAAGAG }\end{array}$ $\begin{array}{cccccc}130 & 140 & 150 & 160 & 170 & 180\end{array}$ $\begin{array}{llllll}190 & 200 & 210 & 220 & 230 & 240\end{array}$

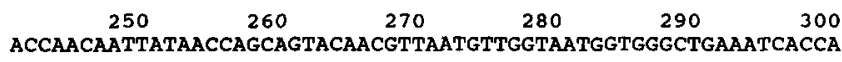

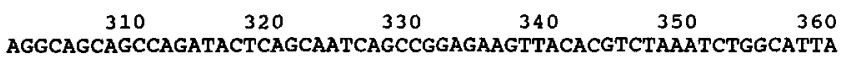
$\begin{array}{llllll}370 & 380 & 390 & 400 & 410 & 420\end{array}$ AATTCACGGTGGAATAATGAAAGTTACCGCTAATGGCAAGACATTCAACTTCCCTGATGG $\begin{array}{llllll}430 & 440 & \text { PstI } & 460 & 470 & 480\end{array}$ AACCAGCACAGAAGACATCGGCGCTGCAGTTGATGAGTATTTTGCAGGGCAGGCATCAGC $\begin{array}{llllllllllllllllllll}T & S & T & E & D & I & G & A & A & V & D & E & Y & F & A & G & Q & A & S & A\end{array}$

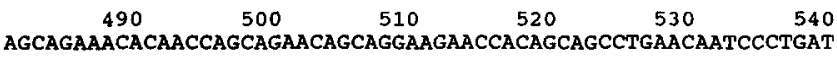

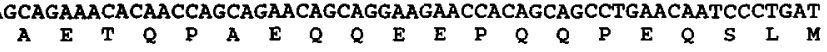
$\begin{array}{llllll}550 & 560 & 570 & 580 & 590 & 600\end{array}$ GCAACGGGCTGGTGACTTACTCACTGGCGGCCAGTCAGCAGGCCAGATTGCAGAGCAGGC

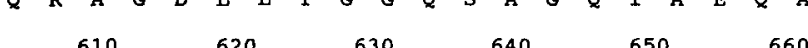
TGGGCGTGGGCTCGTAAATATCCCGTTTGATGTATTGCAGGGCGGCGCGAGTCTCATTAA $\begin{array}{llllllllllllllllllll}G & R & G & L & V & N & I & P & F & D & V & L & Q & G & G & A & S & L & I & N\end{array}$ $\begin{array}{llllll}670 & 680 & 690 & 700 & 710 & 720\end{array}$ CGCAATCAGCCAAGGGTTAGGCGGCCCGAAAGTGCTGGATGACGTGTATCGCCCGGTAGA

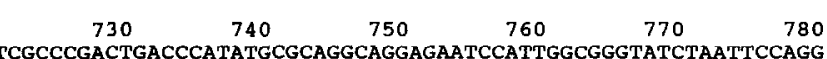

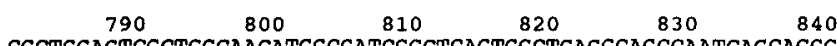
CGCTGGAGTCGCTGGCAACATGGCGATCGGCTCAGTGGCTGAGGCAGCCAATCAGCAGGG $\begin{array}{llllllllllllllllllll}\text { A } & G & V & A & G & N & M & A & I & G & S & V & A & E & A & A & N & Q & Q & G\end{array}$ $\begin{array}{ccccr}850 & 860 & \text { SaCII } 880 & 890 & 900 \\ \text { AGATTTTGCTGGCAACGTTGCGAAGAATGCCGCGGTAACCTCGGCGCTCAGGGGCTACT }\end{array}$ $\begin{array}{lllllllllllllllllllll}D & F & A & G & N & \text { V } & A & \text { K } & \text { N } & \text { A } & \text { A } & \text { V } & \text { N } & \text { L } & G & \text { A } & \text { Q } & \text { G } & \text { L } & \text { L }\end{array}$

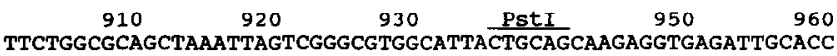

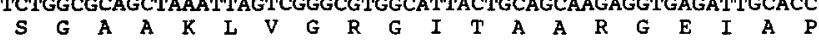

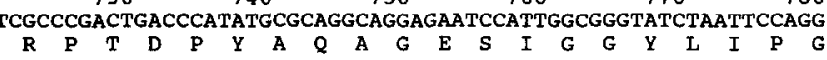

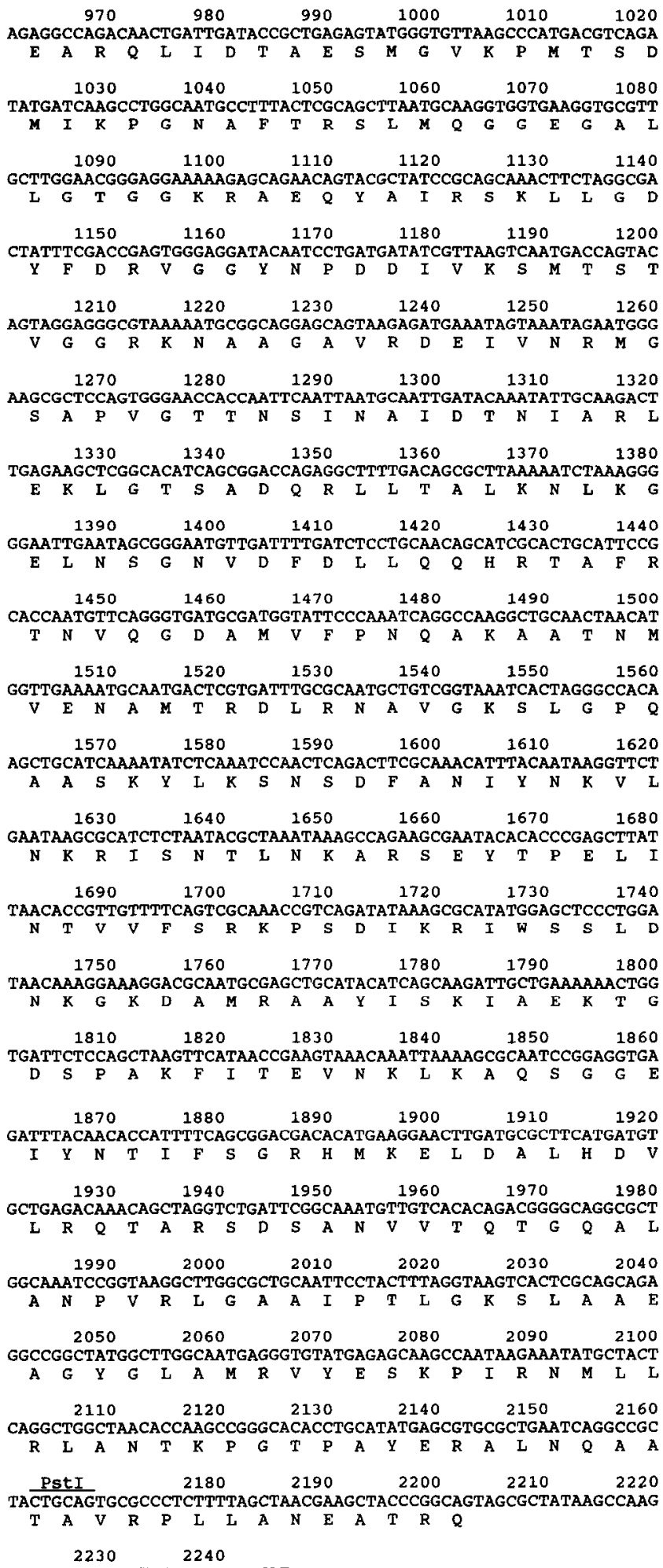

GACGGCATTTATTTTTATAGTTTTPAT

Fig. 3. Nucleotide sequence of the 2.2-kb DNA fragment containing gene 16. The deduced amino acid sequence of gene product 16 is shown below the nucleotide sequence. 


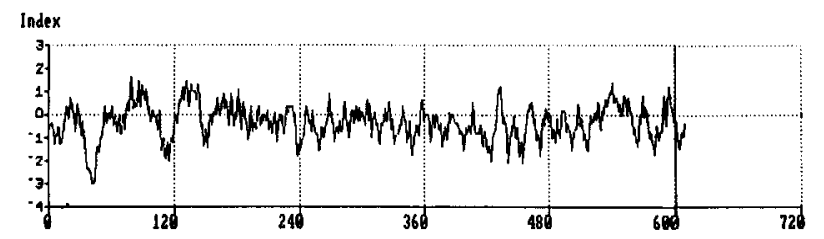

FIG. 4. Hydropathic plot of gene product 16 according to Kyte and Doolittle (1982). The hydropathic plot was performed at a span setting of 9 .

the $5^{\prime}$ part of gene 16 by exchanging a PStI DNA fragment of gene 16 (position 444 to 2163 , Fig. 3 ) for the Pstl lacZ cassette of plasmid pMC1871 (Pharmacia). The $\beta$-galactosidase activity of the fusion protein was determined and compared with the activity of $\beta$-galactosidase from a plasmid with an intact lacZ gene expressed from the tac promoter. For both plasmids a $\beta$-galactosidase activity of about $110-130$ units was determined when cells were grown in the presence of IPTG, indicating that the promoter and the Shine-Dalgarno sequence of plasmid pBU316 allow high expression after induction. Without induction, the $\beta$-galactosidase activity was about 10 units. Therefore it is possible that although gene 16 is well expressed, protein 16 has only a short half-life and is rapidly degraded by proteases. To test this hypothesis, plasmids pBU216 and $\mathrm{pBU} 316$ were introduced into a lon mutant of $E$. coli. After thermic inactivation of the La protease and induction of the tac promoter by IPTG, overproduction of a $64-\mathrm{kDa}$ protein was observed (Fig. 5). Thus it seems that gp 16 indeed is quite rapidly degraded in $E$. coli. In a further experiment we wanted to test whether gp16 is sensitive to protease degradation only during its synthesis or also in its native form. Therefore, after 3 $\mathrm{hr}$ of induction at nonpermissive temperature, the tem-

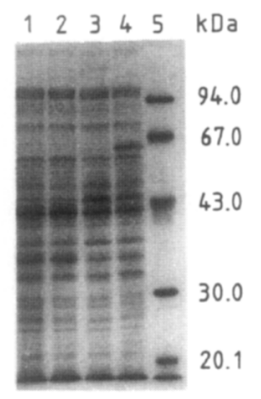

Fig. 5. Overproduction of gene product 16 in E. coli. SDS-PAGE $(17.5 \%)$ of total protein from induced and uninduced cells. Induction was performed by adding $2 \mathrm{mM}$ IPTG to the cells at a titer of $3 \times$ $10^{8} / \mathrm{ml}$ followed by incubation at $37^{\circ}$ for $3 \mathrm{hr}$. E. coli lon mutants were incubated for $20 \mathrm{~min}$ at $42^{\circ}$ to inactivate the La protease prior to induction. Lane 1, LC137 pBU216 uninduced; lane 2, LC137 pBU2 16 induced; lane 3, LC137 pBU316 uninduced; lane 4, LC137 pBU316 induced; lane 5, marker proteins.

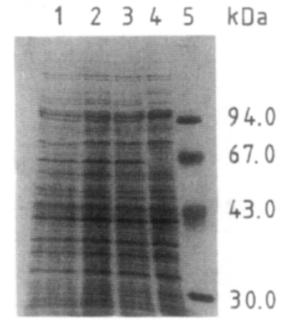

FiG. 6. Dependence of gene product 16 abundance on La protease activity. SDS-PAGE $(15 \%)$ of total protein from induced cells (E. coli LC137 pBU316). Cells were induced by the addition of $2 \mathrm{mM}$ IPTG after inactivation of La protease by incubation at $42^{\circ}$ for 20 min. Lane $1,5 \mathrm{hr}$ induction at $37^{\circ}$; lane $2,3 \mathrm{hr}$ at $37^{\circ}$ followed by $2 \mathrm{hr}$ at $28^{\circ}$ to allow synthesis of La protease; lane $3,3 \mathrm{hr}$ at $37^{\circ}$; lane 4 , uninduced cells; lane 5 , marker proteins.

perature was shifted down to $28^{\circ}$ for $2 \mathrm{hr}$ to allow the synthesis of active La protease. There was no visible difference in the amount of gp16 between cells with inactivated and reactivated La protease (Fig. 6). It seems that once it has its native conformation, gp 16 is no longer degraded by the La protease.

\section{Some aspects of the biological function of gene product 16}

The gene product 16 produced from a plasmid is able to complement gene 16 mutants. Plating of the progeny phages on suppressing and nonsuppressing hosts showed that the gp16 is incorporated into the phage particle of progeny phages. These progeny phages behave like mutant phages grown on a suppressing host.

It has been shown that $16^{-}$particles can be complemented at the membrane, if gp 16 is supplied from outside the cell by a helper phage (Hoffman and Levine, 1975a). To test whether gp16 can also complement $16^{-}$particles from inside the cell, we infected $S$. typhimurium su ${ }^{-}$pBU5 16 with $16^{-}$phage particles. The infective center assay was done as described (Hoffman and Levine, 1975a). The results of Table 1 show that complementation at the membrane is not possible from inside the cell. Complementation is possible from outside the cell by a helper phage (P22 12 amH80), indicating that the phage lysate contained $16^{-}$particles.

It has been suggested that gp16 of P22 might be a pilot protein (Hoffman and Levine, 1975b; Bryant and King, 1984). Pilot proteins of phages with linear DNA are thought to protect the DNA against degradation by the RecBCD nuclease. A well-studied example for such a pilot protein is the gene 2 protein of bacteriophage T4 (Lipinska et al., 1989). It has been shown that gene 2 mutants of $\mathrm{T} 4$ are able to infect recBCD mu- 


\section{TABLE 1}

Infective Center Assay for $16^{-}$ts Defective P22 Particles

\begin{tabular}{|c|c|c|c|}
\hline Plasmid & Phage & moi & $\begin{array}{c}\text { Infective } \\
\text { centers/ml } \\
\text { infected culture }\end{array}$ \\
\hline - & $16^{-}$ts Defective particles & 0.5 & $1.1 \times 10^{7}$ \\
\hline - & $12 \mathrm{amH} 80$ & 5 & $1.1 \times 10^{4}$ \\
\hline \multirow[t]{2}{*}{-} & $16^{-}$ts Defective particles & 0.5 & \\
\hline & $+12 \mathrm{amH} 80$ & 5 & $2.7 \times 10^{8}$ \\
\hline pBU5 16 & $16^{-}$ts Defeclive particles & 0.5 & $9.0 \times 10^{6}$ \\
\hline
\end{tabular}

Note. Salmonella typhimurium $\mathrm{su}^{-}$was infected at a titer of $1 \times$ $10^{8} / \mathrm{ml}$. Adsorption was done at $25^{\circ}$ for $15 \mathrm{~min}$. Unadsorbed phage were removed by centrifugation. Resuspended, infected cells were plated with indicator cells ( $S$. typhimurium $\mathrm{Su}^{-}$) and incubated at $28^{\circ}$.

tants successfully (Silverstein and Goldberg, 1976). We have tested whether a gene 16 mutant of P22 can also grow on recBCD mutants. In such an experiment we observed no increase in the efficiency of plating of phage mutants on suppressor-negative $S$. typhimurium recB mutants compared to the e.o.p. on wildtype cells. In both cases the plaques obtained $\left(2 \times 10^{4} / \mathrm{ml}\right)$ were due to wildtype revertants. Pilot proteins probably bind to the end of the linear phage DNA, but they do not require specific DNA sequences. Therefore the pilot proteins of phages T4 and Mu are interchangeable, and the pilot protein of phage Mu enables gene 2 mutants of T4 to grow on a suppressor-negative strain (Schaus and Wright, 1980). In order to determine if this was also accomplished by gp 16 of $\mathrm{P} 22, E$. coli $\mathrm{Su}^{-}$ carrying plasmid pBU5 was infected by a gene 2 mutant of phage T4 grown on a suppressor-free $E$. coli recBCD. The efficiency of plating of phage T4 did not increase in comparison to a plasmid-free strain. While the phage titer was about $1 \times 10^{10}$ on a recBC host, the titer was about $3 \times 10^{7} / \mathrm{ml}$ on JM101 and JM101 pBU5.

\section{DISCUSSION}

We have cloned and overexpressed gene 16 of bacteriophage P22. The nucleotide sequence includes an open reading frame encoding a protein of 609 amino acids with a molecular weight of 64,366 . Recently the eight aminoterminal amino acids of gp 16 isolated from phage particles have been determined (Eppler et al., 1991). This amino acid sequence agrees with that deduced from the nucleotide sequence beginning at nucleotide 377 (Fig. 3). There are no membrane-spanning regions in either part of the protein arguing against the possibility that gp 16 forms a membrane pore for DNA transport (Goldberg, 1980; Labedan and Goldberg, 1981). It could be shown, for example, that gp3 of phage fd can oligomerize and form an aqueous pore (Glaser-Wuttke et al., 1989). The gp3, although it does not have many $\alpha$-helical domains, exhibits at least several possible membrane-spanning regions. Gene product 16 itself is probably not a transmembrane protein, but the possibility remains that gp16 could modify a preexisting pore or form a pore in interaction with other proteins.

The protein 16 does not protect P22 DNA from degradation by the RecBCD enzyme. It also cannot substitute for the gene product 2, the pilot protein of phage T4. Therefore, it is not likely that gp 16 is a pilot protein in the sense that it binds to the end of linear DNA protecting it from degradation by exonucleases. However, it cannot be ruled out that gp 16 is a pilot protein acting by another mechanism than known for gp 2 from phage T4. It has also been suggested that gp 16 may interact with gp20 and/or gp7 in guiding the DNA across the membrane. Supporting this is a recent report that gp 16, if purified from procapsids, is complexed with gp20 (Thomas and Prevelige, 1991).

Protein 16 is only overproduced when its gene is under the control of a strong promoter and a ShineDalgarno consensus sequence in a lon mutant of $E$. coli. At present, overproduction has only been shown in E. coli. It would be interesting to know if the half-life time is as short in Salmonella strains, the natural host, as in E. coli. Since protein 16 is probably needed only during the injection of DNA, it could be convenient that it is rapidly degraded when it has fullfilled its function during the infection process. When gp 16 is produced during late stages of phage development, the protein may be incorporated very rapidly into the proheads (Thomas and Prevelige, 1991) and thus be protected from degradation by proteases. Protein 16 may also be protected from degradation by forming oligomers or a complex, for example, with gp20. Reactivation experiments of protease La showed that gp16 is indeed a substrate for the protease only during synthesis. The native protein is no longer degraded.

Overproduction of gp 16 in E. coli renders it possible to purify the protein in sufficient amounts for further studies. It will be possible to test DNA binding, a prerequisite for a pilot protein. With the help of antibodies it may be possible to determine the location of the protein after infection.

\section{ACKNOWLEDGMENTS}

We thank R. Eichenlaub for helpful discussions and critical reading of the manuscript. This work was supported by the Deutsche Forschungsgemeinschaft. Sequence data of gene 16 have been deposited with the EMBL/GenBank Data Libraries under Accession No. M74136. 


\section{REFERENCES}

BODE, W., DopatKA, H. D., and PRELL, H. H. (1973). Functional classification of P22 amber mutants. Mol. Gen. Genet. 127, 341-347.

BOTSTEIN, D., WADDELL, C. H., and KING, J. (1973). Mechanism of head assembly and DNA encapsulation in Salmonella phage P22. I. Genes, proteins, structures and DNA maturation. J. Mol. Biol. 80 , 669-695.

BRYANT, J. L., and KING, J. (1984). DNA injection proteins are targets of acridine sensitized photoinactivation of bacteriophage P22. J. Mol. Biol. 180, 837-863.

CASJENS, S., and ADAMS, M. B. (1985). Posttranscriptional modulation of bacteriophage P22 scaffolding protein gene expression. $J$. Virol. 53, 185-191.

Chisholm, R. L., Deans, R. J., Jackson, E. N., Jackson, D. A., and RUTILA, J. E. (1980). A physical map of the bacteriophage P22 late region: Genetic analysis of cloned fragments of P22 DNA. Virology 102, 172-189.

Eppler, K., Wyckoff, E., GoATes, J., PARR, R., and CASJens, S. (1991). Nucleotide sequence of the bacteriophage $\mathrm{P} 22$ genes required for DNA packaging. Virology 183, 519-538.

Fürste, J. P., Pansegrau, W., Frank, R., Blöcker, H., Scholz, P., BAGDASARIAN, M., and LANKA, E. (1986). Molecular cloning of the plasmid RP4 primase region in a multi-host-range tacP expression vector. Gene 48, 119-131.

GLASER-WUTtKE, G., KePPNER, J., and RASChed, I. (1989). Pore-forming properties of the adsorption protein of filamentous phage $\mathrm{fd}$. Biochim. Biophys. Acta 985, 239-247.

Goloberg, E. (1980). Bacteriophage nucleic acid penetration. In "Receptors and recognition: Virus receptors" (L. Randall and L. Philipson, Eds.), Series B, Vol. 7, pp. 115-141. Chapman \& Hall, London.

Hoffman, B., and LeVine, M. (1975a). Bacteriophage P22 virion protein which performs an essential early function. I. Analysis of $16^{-}$ts mutants. J. Virol. 16, 1536-1546.

HoffMAN, B., and LeVINE, M. (1975b). Bacteriophage P22 virion protein which pertorms an essential early function. II. Characterization of the gene 16 function. J. Virol. 16, 1547-1559.

ISRAEL, V. (1977). E proteins of bacteriophage P22. I. Identification and ejection from wild-type and defective particles. J. Virol. 23, $91-97$.

KYTE, J., and DoOLITTLE, R. F. (1982). A simple method for displaying a hydropathic character of a protein. J. Mol. Biol. 157, 105-132.

LABEDAN, B., and GOLDBERG, E. B. (1981). DNA transport across bacterial membranes. In "Membranes and Transport" (A. N. Martinosi, Ed.), Vol. 2. pp. 133-138. Plenum, New York.

LAEMMLI, U. K. (1970). Cleavage of structural proteins during the assembly of the head of bacteriophage T4. Nature (London) 227, $680-685$.

LANKA, E., and BARTH, P. T. (1981). Plasmid RP4 specifies a deoxyribonucleic acid primase involved in its conjugal transfer and maintenance. J. Bacteriol. 148, 769-781.

LIPINSKA, B., RAO, A. S. M. K., BOLTEN, B. M., BALAKRISHNAN, R., and GoldBERG, E. B. (1989). Cloning and identification of bacteriophage T4 gene2 product gp2 and action of gp2 on infecting DNA in vivo. J. Bacteriol. 171, $488-497$.

Maniatis, T., Fritsch, E. F., and SAmbrook, J. (1982). In "Molecular Cloning: A Laboratory Manual," p. 250. Cold Spring Harbor Laboratory, Cold Spring Harbor, NY.

Sanger, F., Nicklen, S., and Coulson, A. R. (1977). DNA sequencing with chain-termination inhibitors. Proc. Natl. Acad. Sci. USA $74,5463-5467$

SCHAUS, N. A., and WRIGHT, A. (1980). Inhibition of Escherichia coli exonuclease $V$ by bacteriophage Mu. Virology 102, 214-217.

SilverSTEIN, J. L., and GoldBeRG, E. B. (1976). T4 DNA injection. II. Protection of entering DNA from host exonuclease V. Virology 72 , 212-223.

TABOR, S., and RICHARDSON, C. C. (1987). DNA sequence analysis with a modified bacteriophage T7 DNA polymerase. Proc. Natl. Acad. Sci. USA 84, 4767-4771.

ThomAs, D., and PreVelige, P. (1991). A pilot protein participates in the initiation of $P 22$ procapsid assembly. Virology $182,673-681$.

VIEIRA, J., and MESSING, J. (1982). The pUC plasmids, an M13mp7-derived system for insertion mutagenesis and sequencing with synthetic universal primers. Gene 33, 103-119.

YOUDERIAN, P., and SUSSKIND, M. M. (1980). Identification of the products of bacteriophage $P 22$ genes, including a new late gene. Virology $107,258263$. 